\title{
Segurança e justiça: o acordo de não persecução penal e sua compatibilidade com o sistema acusatório*
}

\author{
Recebido: 25 de julho de 2019 • Aprovado: 14 de setembro de 2019 \\ https://doi.org/10.22395/ojum.v19n38a6 \\ Claudio José Langroiva Pereira** \\ Bruno Girade Parise***
}

\section{RESUMO}

A segurança pública envolve diretamente a segurança jurídica e a segurança das instituições democráticas. A partir do reconhecimento pelo Supremo Tribunal Federal brasileiro da constitucionalidade de investigações penais serem realizadas diretamente pelo Ministério Público, sem a presidência da autoridade policial, o Conselho Nacional do Ministério Público cumpriu determinação de regulamentar a questão, em âmbito institucional, quando editou a Resolução 181, de 7 de agosto de 2017. Além da regulamentação da investigação, a Resolução também prevê em seu artigo 18 o "acordo de não persecução penal".

Diante desse cenário, o artigo tem como objetivo geral avaliar a Resolução e o referido ins tituto. Para isso, toma como premissas a Constituição Federal brasileira, o sistema acusatório, os princípios da legalidade e da reserva legal.

Como objetivo específico, o texto pretende analisá-los sob a ótica do devido processo legal (penal) e dos direitos e garantias fundamentais do cidadão no Estado Democrático de Direito brasileiro. A questão que impulsiona a investigação, ligada diretamente à segurança jurídica e à segurança das instituições democráticas, está em saber se ao propor uma modificação no Processo Penal por meio de Resolução, com acordos realizados antes da denúncia e com contrapartidas assemelhadas à pena, o órgão ministerial obedeceu ao sistema processual vigente.

O estudo utiliza como método, predominantemente, a revisão bibliográfica e procura traçar um diálogo entre autores contemporâneos sobre o tema em questão.

Palavras-chave: segurança pública; justiça penal negociada; justiça transacional; sistema acusatório; acordo de não persecução penal; Ministério Público; princípio da legalidade; princípio da obrigatoriedade; princípio da oportunidade; jurisdicionalidade.

\footnotetext{
* O artigo integra a produção intelectual do Grupo de Pesquisa Políticas Públicas de Segurança e Direitos Humanos da Pontifícia Universidade Católica de São Paulo (PUC-SP).

** Doutor em Direito das Relações Sociais, Professor Doutor de Direito Processual Penal da Pontifícia Universidade Católica de São Paulo (PUC-SP), Líder do Grupo de Pesquisa "Políticas Públicas de Segurança e Direitos Humanos". E-mail: claudiopereira@pucsp.br. Orcid: https://orcid.org/0000-0002-2067-4980

*** Graduado em Direito, Mestrando em Direito Processual Penal na Pontifícia Universidade Católica de São Paulo (PUC-SP), membro do Grupo de Pesquisa "Políticas Públicas de Segurança e Direitos Humanos". E-mail: brunoparise@hotmail.com
} 


\section{Seguridad y justicia: el acuerdo de no persecución penal y su compatibilidad con el sistema acusatorio}

\section{RESUMEN}

La seguridad pública implica directamente la seguridad jurídica y la seguridad de las instituciones democráticas. Desde el reconocimiento por parte de la Corte Suprema Federal de Brasil de la constitucionalidad de las investigaciones penales que se llevan a cabo directamente por el Ministerio Público, sin la presidencia de la autoridad policial, el Consejo Nacional del Servicio de Fiscalía Pública cumplió con la determinación de regular el problema, a nivel institucional, al emitir la Resolución 181, del 7 de agosto de 2017. Además de la regulación de la investigación, la Resolución también establece en su artículo 18 el "acuerdo de no persecución penal".

Ante este escenario, el objetivo general del artículo es evaluar la Resolución y ese instituto. Para ello, toma como premisas la Constitución Federal brasileña, el sistema acusatorio, los principios de legalidad y la reserva legal.

Como objetivo específico, el texto pretende analizarlos desde la perspectiva del debido proceso (penal) y los derechos y garantías fundamentales del ciudadano en el Estado de Derecho Democrático brasileño. El tema que impulsa la investigación, directamente relacionado con la seguridad jurídica y la seguridad de las instituciones democráticas, es saber si al proponer una modificación del Procedimiento Penal mediante resolución, con acuerdos realizados antes de la denuncia y con contrapartes similares a la pena, la Fiscalia siguió el sistema procesal actual.

El estudio utiliza como método, predominantemente, la revisión de la literatura, y busca establecer un diálogo entre autores contemporáneos sobre el tema en cuestión.

Palabras clave: seguridad pública; justicia penal negociada; justicia transicional; sistema acusatorio; acuerdo de no persecución penal; fiscalía; principio de legalidad; principio de obligación; principio de oportunidad; jurisdiccionalidad.

\section{Security and Justice: the Non-Criminal Prosecution Agreement and its Compatibility with the Prosecuting System}

\section{ABSTRACT}

Public safety and security directly involve both legal certainty and the security of democratic institutions. Since the acknowledgement by the Brazilian Federal Supreme Court of the constitutionality of criminal investigations being carried out directly by the Public Prosecution Service, without police direction, the National Council of the Public Prosecution Service complied with the determination to regulate the matter, at institutional level, issuing the Resolution 181, of August 7, 2017. Further to the regulation of the investigation, the Resolution also provides in its article 18 the "non-criminal prosecution agreement".

Given this scenario, the main aim of this paper is to assess the Resolution and the referred institute, taking as its premises the Brazilian Federal Constitution, the accusatorial system, the principles of legality and the legal reserve.

As a specific objective, the article seeks to analyze those from the perspective of proper (criminal) legal proceedings, as well as the fundamental rights and guarantees of the citizen in the Brazilian Democratic State of Law. The issue that drives the investigation, directly anchored to the legal certainty and the security of democratic institutions, is whether by proposing an alteration of the Criminal Procedure through Resolution - with agreements made before the denunciation and with counterparts similar to the penalty — the ministerial body has conformed to the current procedural system.

The prevailing methodology of this research was a literature review, seeking to open a dialogue between contemporary authors on the subject matter.

Keywords: public safety and security; negotiated criminal justice; transitional justice; accusatory system; non-criminal prosecution agreement; Public Ministry; principle of legality; principle of obligation; opportunity principle; jurisdiction. 


\section{INTRODUÇÃOO}

Em meados de 2017, o Conselho Nacional do Ministério Público editou a Resolução 181, que trouxe em seu bojo — para além da controvertida questão da investigação realizada pelo órgão ministerial — o chamado "acordo de não persecução penal", modalidade de justiça penal negociada que acarreta o não oferecimento da denúncia em determinados delitos, caso o investigado seja confesso e arque com medidas restritivas de direitos. Apesar de seu conteúdo impactante, tal inovação restou desprovida do necessário debate prévio,deixando à comunidade jurídica apenas sua análise posterior, missão principal do presente artigo.

Para tanto, a tarefa primeira será fixar o padrão de confronto de qualquer regulamentação nessa área, e definir qual sistema processual penal - garantista ou meramente instrumental - é adotado no Brasil, especialmente diante da visível dicotomia entre parcela da sociedade que brada por um processo penal não impeditivo da punição célere e aqueles que possuem uma concepção histórica de limitação do poder estatal de punir por meio de barreiras impostas pelo processo.

Nesse passo, para se impor como paradigma comparativo, não basta ao sistema processual penal estar legalmente ou até constitucionalmente disposto, mas também deve superar o confronto com o conceito jusfilosófico de justiça, que parte de premissa encontrada em estudo da obra do autor argelino Albert Camus, para quem a justiça trafega ora entre o direito e ora em seu avesso, a ilegalidade. Ultrapassado o duplo crivo - legal e justo - o sistema processual penal estará apto a inibir inovações contrárias aos seus preceitos.

Nessa ordem de ideias, a partir das conclusões até então alcançadas, restou ao estudo promover a compatibilização do acordo de não persecução penal com o sistema processual penal erigido como legal e justo - caso se compatibilize, com especial enfoque em três temas: a modificação de estruturas processuais penais por meio de Resolução, a realização de acordos antes mesmo da peça inicial acusatória e a mitigação da obrigatoriedade conferida ao Ministério Público de dar início à ação penal de iniciativa pública quando se deparar com crimes dessa natureza.

Em suma, por meio de revisão bibliográfica, o presente estudo pretende solucionar a seguinte questão: o acordo de não persecução penal trazido pela Resolução 181 do Conselho Nacional do Ministério Público obedece ao sistema processual penalestabelecido no Brasil?

\section{REFLEXÕES INICIAIS SOBRE DIREITO E JUSTIÇA}

Quando se começa a tratar de temas que envolvem direito e justiça, não é possível o afastamento de conflitos como os que Couture (1987) destaca: "teu de- 
ver é lutar pelo direito, mas se um dia encontrares o Direito em conflito com a justiça, luta pela justiça" (p. 10).

Muito além dos aspectos motivacionais que essas sentenças apresentam, uma afirmação como essa concretiza a separação estrutural entre os dois vocábulos, o que afasta a justiça do critério puramente positivista do direito. Afinal, nem tudo o que é lei será justo, e é marcante a memória do regime nazista no qual o princípio do "afrouxamento" permitiu a flexibilização de todo o sistema processual penal, que reduziu ao mínimo indispensável os "freios", as preclusões e os obstáculos à atividade jurisdicional (que passou a ser a de persecução penal), com o fim de se descobrir uma denominada "verdade" e assim alcançar uma justiça material, ainda que suas consequências implicassem em exílio ou exterminação (Negri, 2010 como citado em Coutinho, 2015). Tudo se deu em um Estado de Direito e de forma legal, e cabe relembrar que tudo o que é justo não será necessariamente legal e constitucional.

Nesse passo, se a discussão acerca do conceito de justiça parece infindável no campo jusfilosófico, interessante é o pensamento de Albert Camus ${ }^{1}$, para quem a justiça — por não ser estática, tampouco absoluta — trafega ora pelo direito ora pelo seu avesso, a ilegalidade. Nessa ordem de ideias, para se alcançar o ideal justo não basta a mera leitura da norma, mas sua análise histórica, conjuntural e principalmente democrática, conforme explicita Granduque José (2017):

Assim, em Camus, a justiça está entre o avesso e o direito. Para que ela remanesça viva, diferentemente da justiça eterna com a qual sonham cristãos e comunistas, a justiça deverá permanecer em movimento por esses dois polos enquanto o direito moderno ainda estiver em nosso horizonte histórico. Desse modo, muitas vezes a justiça estará no avesso, ou seja, na ilegalidade, tomando-se a lei como fonte primordial do direito moderno, como por exemplo, quando advieram as Leis antissemitas de Nuremberg, mas também ela poderá ser encontrada no direito posto, como, por exemplo, ocorria com a República espanhola, em defesa da qual Camus não cessou de invocar a legalidade e a constitucionalidade com base nas quais ela se instituiu². (p. 259)

1 Conforme se observa de trecho da obra: "A justiça em um mundo silencioso, a justiça escravizada e muda destrói a cumplicidade e finalmente não pode mais ser a justiça. A revolução do século XX separou arbitrariamente, para fins desmedidos de conquista, duas noções inseparáveis. A liberdade absoluta zomba da justiça. A justiça absoluta nega a liberdade. Para serem profícuas, ambas as noções devem encontrar uma na outra seus limites. Nenhum homem considera a sua condição livre, se ela não é justa ao mesmo tempo, nem justa, se ela não se acha livre" (Camus, 2005, p. 334).

2 Nesse ponto, é interessante salientar que o autor explorou com excelência a obra de Camus, que por sua vez não se dispôs a fazer uma análise meditada sobre o direito em sua vasta obra. Todavia, para compreender a visão de Albert Camus sobre o fenômeno jurídico, o autor foi juntando fios esparsos de pensamento, que aparecem em artigos para jornais, romances, peças de teatro e ensaios filosóficos. Surge, então, para o autor, a partir de Camus, a ideia de que a justiça está entre o avesso e o direito, em uma conclusão que alcançou ao captar o movimento das obras de Camus e identificar esses fios esparsos que versam sobre direito, lei e justiça. O autor seleciona na obra de Camus reflexões claras e diretas sobre a ideia de equilíbrio e submissão a limites de justiça, bem como que os fins não justificam os meios. 
Tal posicionamento é importante para o processo penal contemporâneo, cuja acentuada dicotomia entre os operadores do direito ganha contornos inconciliáveis quando seus atos jurídicos estão sujeitos ao crivo social. De um lado, avalizados pelo clamor público midiático ${ }^{3}$, estão os que bradam pela rápida condenação do réu por meio de um processo penal meramente instrumental e desprovido de "barreiras" e, de outro, os que reclamam por um sistema de proteção ao acusado frente ao poder punitivo estatal, o chamado "modelo garantista"

Assim, em um primeiro aspecto, é necessário definir em qual das duas direções caminhou o ordenamento jurídico brasileiro, em especial a partir da leitura dos dis positivos constitucionais da Carta Magna de 1988. Em um segundo momento, considerando o postulado de Albert Camus ${ }^{5}$, fixa-se como imperativo que o modelo legalmente eleito também passe por uma filtragem, segundo os critérios de justiça democraticamente considerada.

Somente assim, ultrapassado o duplo crivo — legal e justo — o modelo estará apto a ser a matriz argumentativa e interpretativa do processo penal. Ou seja, toda e qualquer discussão, legislativa ou não, deve ter como ponto de partida o sistema processual adotado.

Em face destes elementos surge a necessidade de discutir aspectos da Segurança Pública, em seu conceito amplo, que envolve a segurança jurídica e a segurança institucional.

É nesse contexto que merece análise o denominado "acordo de não persecução penal", previsto na Resolução 181, do Conselho Nacional do Ministério Público.

A questão que impulsiona a investigação, ligada diretamente à segurança jurídica e à segurança das instituições democráticas, está em saber se ao propor uma modificação no Processo Penal por meio de Resolução, com acordos realizados antes da

3 Éa incontestável influência daquilo que Sanguiné (2001, p. 269) denomina de quarto poder, a mass media e a opinião pública. Ademais, em excelente obra, Casara (2015, p. 197) ensina que a cultura punitivista da sociedade é normalmente embasada na crença mitológica do processo penal como instrumento de pacificação social ou de segurança pública.

4 A evidente instrumentalidade do processo penal referente ao direito material deve ser lida sob a ótica do que Lopes Jr. (2014, p. 53) denominou de "instrumentalidade constitucional do processo penal", e, em sua obra clássica, Prado (2005) leciona: "[...] o processo penal não é apenas o instrumento de composição do litígio penal ou de resolução de causas penais, mas, sobretudo, um instrumento político de participação, com maior ou menor intensidade, conforme evolua o nível de democratização da sociedade. Para tanto, afigura-se imprescindível a coordenação entre direito, processo e democracia, o que ocorre pelo desejado caminho da Constituição" (p. 75).

5 Em outra passagem, o autor afirma: "em sociedade, não há justiça sem direitos naturais ou civis que a fundamentem. Não há direito sem expressão desse direito. Se o direito se exprimir sem hesitação, é provável que mais cedo ou mais tarde a justiça por ele pleiteada venha ao mundo" (Camus, 2005, p. 333). 
denúncia e com contrapartidas assemelhadas à pena, o órgão ministerial obedeceu ao sistema processual vigente.

Estamos diante da discussão de instituto de negociação penal que, no Brasil, recebe grande influência do sistema estadunidense ${ }^{6}$. Este, por sua vez, apresenta um histórico de práticas pouco ortodoxas (com base no nosso sistema acusatório no Estado Democrático de Direito brasileiro) realizadas pelos órgãos oficiais de acusação, principalmente quando da busca da condenação de grandes integrantes do crime organizado, em "trocas" questionáveis de benefícios aos delatores e suas famílias (O Globo, 2019), o que proporciona a contrassenso a ideia de medida ilegal, ilegítima e propagadora de impunidade (Pereira, 2002, p. 285), e permite um profundo questionamento moral sobre como se deve operar a negociação penal.

Aqui vale ainda a lembrança de Sen (2011), para quem "temos de enfrentar dúvidas, questões, argumentos e análises para saber se e como é possível promover a justiça". (p. 424)

\section{A ESCOLHA CONSTITUCIONAL PELO MODELO ACUSATÓRIO GARANTISTA: UMA NECESSIDADE DEMOCRÁTICA}

Ainda em constante evolução na busca da plena efetividade, a Constituição da República Federativa do Brasil de 1988 teve o condão de dissipar incertezas acerca da sua missão redemocratizadora, o que elevou e ampliou direitos fundamentais.

Nesse aspecto, a Carta Magna de 1988 fez a clara opção política por um sistema jurídico de garantias aplicáveis ao acusado em um processo criminal, alicerçado no princípio da presunção de inocência. Ainda, em seu artigo 129, I, estabeleceu a titularidade da ação penal de iniciativa pública ao Ministério Púbico, característica intrínseca e principal de um modelo acusatório:

No plano normativo, a opção marcada na Constituição da República de 1988 foi clara: ao se conferir a exclusividade no exercício da ação penal de iniciativa pública ao Ministério Público, bem como se assegurar direitos fundamentais ao réu, tais como contraditório e ampla defesa, decidiu-se por um processo de partes e por um juiz imparcial, portanto, pelo sistema acusatório. (Casara e Melchior, 2013, p. 95)

Aliás, a retomada da democracia é evidentemente incompatível com qualquer sistema inquisitivo de processo penal, traço marcante de épocas como das "inquisições", nas quais o réu não era parte do processo, mas seu objeto (Badaró, 2014,

6 Em interessante menção acerca da influência estaduninese nos processos penais latinos, Maldonado e Chorres, (2011) afirmam que "Un claro ejemplo lo tenemos com la figura del juez de garantia o de control. Esta figura es inexistente el proceso penal norteamericano. Pero porque no existe em Estados Unidos, los latinos no lo vamos a tomar? La resposta es obvia: si em Latinamerica es uma constante el instrumentalizar la justicia penal como medio de violacion de los derechos humanos, entonces necesitamos disminuir tais tales actos, a traves de mecanismos o instituciones de control, como es el juez de garantía. Si Estados Unidos no lo tiene, no es nuestro assunto" (p. 68). 
p. 47); sistema detentor da famigerada "verdade real" e, portanto, sujeito à utilização da tortura para obtê-la (Eymerich, 1993).

Conforme anota Ferrajoli (2002), "a batalha cultural e política contra a irracionalidade e o arbítrio desse procedimento (inquisitorial) forma um dos motivos animadores de todo o iluminismo penal reformador" (p. 454), e a consequente revitalização do sistema acusatório (Casara e Melchior, 2013, p. 93). Historicamente, portanto, democracia e sistema acusatório trilharam o mesmo caminho.

Nesse ponto, existem inúmeras críticas às disposições infraconstitucionais (Lopes Junior, 2014, p. 111) que, de certo modo, poderiam desvirtuar o sistema acusatório garantista. Entretanto, como aquilo que está em descompasso com a democrática Constituição brasileira deve ser desconsiderado e até combatido, todos os dispositivos legais que assim se portam devem ser invalidados ou interpretados segundo a Constituição Federal, sob pena de não existirem para o sistema jurídico brasileiro.

Retomando o pensamento de Albert Camus, o ordenamento jurídico brasileiro, regido pelo Estado Democrático de Direito, encontra a justiça processual penal na própria Constituição da República por meio de sua materialização em seu sistema acusatório garantista, que consubstancia o Processo Penal no Direito Constitucional aplicado.

Para Figueiredo Dias (1981, p. 74), o direito processual penal exige, para uma conformação constitucional, uma visão interdisciplinar que, ao ultrapassar o problema jurídico, alcance a ciência política, e assim siga para uma conformação de direito constitucional aplicado ${ }^{7}$. Isso, porque, os fundamentos do Direito Processual Penal são simultaneamente as bases constitucionais do Estado de Direito, no qual a solução de problemas processuais penais invariavelmente é obtida por meio de sua conformação constitucional.

Reforça esse pensamento Roxin (2003, p. 10), quando reconhece no Direito Processual Penal uma espécie de Direito Constitucional em movimento. É certo que a constitucionalização de todo o processo (princípio do devido processo legal — constitucional) é em si o reconhecimento de que toda a persecução penal se submete a uma base constitucional, em especial por reconhecer como indispensável a harmonia entre o processo (penal) e os direitos e garantias fundamentais, assegurados na Constituição Federal.

Enfim, deve-se considerar que o conteúdo democrático é a essência de todo o processo interpretativo, em especial na aplicação do direito processual penal, na medida em que, conforme preceitua Sen (2011):

No mesmo sentido, defendem o Processo Penal como Direito Constitucional aplicado, Canotilho e Brandão (2016, p. 24). Em sentido contrário, Costa (1997, p. 187), que não comunga dessa expressão, relaciona uma série de elementos que devem ser considerados, antes de assumir o Direito Processual Penal como Direito Constitucional aplicado. 
O êxito da democracia não consiste meramente em ter a estrutura institucional mais perfeita que podemos conceber. Ele depende inelutavelmente de nossos padrões de comportamento real e do funcionamento das interações políticas e sociais. Não há nenhuma possibilidade de confiar a matéria às mãos 'seguras' do virtuosismo puramente institucional. O funcionamento das instituições democráticas, como o de todas as outras instituições, depende das atividades dos agentes humanos que utilizam as oportunidades para as realizações razoáveis. (pp. 388-389)

\section{0 SISTEMA ACUSATÓRIO GARANTISTA E O ACORDO DE NÃO PERSECUÇÃO PENAL}

O estudo em questão, neste momento, parte de um debate jurídico estabelecido no Estado brasileiro: a discussão sobre a constitucionalidade de investigações de natureza penal serem realizadas diretamente pelo Ministério Público, sem a presença policial, em especial da autoridade policial como presidente da investigação.

O Supremo Tribunal Federal brasileiro, no ano de $2015^{8}$, reconheceu como constitucional a possibilidade de a investigação ser realizada diretamente pelo Ministério Público, vencida tese da exclusividade policial, mas que ainda atribui ao Conselho Nacional do Ministério Público ${ }^{9}$ a tarefa de regulamentar esta atividade, o que o fez por meio da Resolução 181 (2017).

Ocorre que no artigo 18 da Resolução em foco, o Conselho Nacional do Ministério Público, sem qualquer discussão prévia, decidiu criar uma possibilidade de não oferecimento de denúncia em determinados crimes quando, em comum acordo, o réu se submeter a cumprir com alguma das contrapartidas estabelecidas na Resolução. Essa criação jurídica ficou definida como "acordo de não persecução criminal", nos seguintes termos:

Art. 18. Não sendo o caso de arquivamento, o Ministério Público poderá propor ao investigado acordo de não persecução penal quando, cominada pena mínima inferior a 4 (quatro) anos e o crime não for cometido com violência ou grave ameaça a pessoa, o investigado tiver confessado formal e circunstanciadamente a sua prática, mediante as seguintes condições, ajustadas cumulativa ou alternativamente $[\ldots]$

§ 11. Cumprido integralmente o acordo, o Ministério Público promoverá o arquivamento da investigação, nos termos desta Resolução.

8 RE 593727, julgado em 14.05.2015, que fixou a tese, em repercussão geral: "Ministério Público dispõe de competência para promover, por autoridade própria, e por prazo razoável, investigações de natureza penal, desde que respeitados os direitos e garantias que assistem a qualquer indiciado ou a qualquer pessoa sob investigação do Estado".

9 Órgão, criado em 30 de dezembro de 2004, pela Emenda Constitucional 45, teve sua instalação concluída em 21 de junho de 2005. 
Evidentemente encontramos aqui a criação de um "novo" instituto de negociação penal que, todavia, exige questionamento quanto às bases legais formais de sua criação, além de sua adequação constitucional.

Nesse passo, tratar de mais um tema que envolve a justiça penal negociada, atualmente, exige a reflexão de que, ainda que a teoria não obtenha seu alicerce na prática forense, quando aquela torna esta inviável, a racionalidade deve ser o caminho perseguido, de tal forma que, inadmitir a justiça negocial no processo penal brasileiro, de forma absoluta, é quase "gritar para o vazio"10.

Entretanto, não se deve desconsiderar que, em termos de justiça penal negociada, a "impossibilidade constitucional de excluir-se da apreciação do Judiciário, lesão ou ameaça a direito, por si só exige que se realize a apreciação técnica jurisdicional da negociação, bem como do acordo dela originado" (Pereira, 2002 , p. 100).

Na discussão ora estabelecida, assume-se a premissa de que o réu, no processo penal, não é livre para negociar seu destino, conforme preceitua Schunemann (2013):

Primeiramente, parece-me evidente que não se pode explicar isso através do recurso a um suposto princípio do consenso (konsensprinzip), ainda que os defensores dos acordos frequentemente apelem para esta estratégia. Afinal, a denominação plea agreement, usual nos Estados Unidos, ou a designação alemã Urteilsabsprache, ou na Espanha conformidad, são na verdade um eufemismo, por trás do qual se oculta uma sujeição do acusado à medida de pena pretendida pelo promotor ou pelo juiz enquanto resultado mínimo, submissão esta alcançada através de forte pressão por parte da justiça criminal sobre o acusado. O princípio do consenso é então, de um ponto de vista prático, uma ficção e, em termos teóricos, leva apenas à destruição do liame de conexão entre o processo penal e o direito penal material. Este liame é o único substrato que permite uma condenação com base na verdade material, e não com base em qualquer consentimento do acusado. (p. 257, grifo nosso)

Fixada a base da frágil posição negocial do acusado, esta é ainda mais acentuada no sistema jurídico brasileiro, diante de um pensamento alinhado à flexibilização de garantias processuais penais por parte do próprio Poder Judiciário"l ao enfrentar a matéria. O acordo advindo da negociação penal se torna uma espécie de "única saída" para o réu, sujeito a um tipo de "coação moral irresistível"; a prisão provisória, neste contexto, surgiu como um instrumento hábil na negociação de colaborações premiadas (Canario, 2014).

10 Morais da Rosa e Lopes Jr. (2017), antes críticos do modelo negocial, enunciam: "os juristas desatualizados insistem em excluir os institutos da Justiça Negociada do ambiente processual brasileiro, lutando por manter a ilha moderna do processo penal e o fetiche pela decisão penal de mérito como o único mecanismo de descoberta e de produção de sanções estatais".

11 A garantia da presunção e inocência, por exemplo, é letra morta em nosso ordenamento. Basta saber que $40 \%$ dos presos no Brasil não têm condenação (Depen, 2017). 
Nesse passo, se o sistema negocial não pode ser freado, ao menos deve trilhar os caminhos contornados pelo sistema acusatório, pelos quais as garantias da legalidade e da jurisdicionalidade, por exemplo, não cedem em favor da eficiência laborativa; deve-se buscar o máximo equilíbrio possível, o que nos remete à condição única de um processo penal no Estado Democrático de Direito.

\section{DA VIOLAÇÃO DA RESERVA LEGAL}

A Resolução 181, do Conselho Nacional do Ministério Público, tem natureza jurídica de norma regulamentadora de caráter administrativo. Nesse aspecto, em relação ao disposto no artigo 18, inovou em matéria processual penal e assim, não atendeu aos requisitos mínimos do sistema acusatório penal e suas correspondentes garantias, que carecem da estrita legalidade penal que sustenta o sistema jurídico penal brasileiro ${ }^{12}$.

O artigo 22, I, da Constituição da República Federativa do Brasil é sólido ao mencionar que "compete privativamente à União legislar sobre [...] I — direito civil, comercial, penal, processual, eleitoral, agrário, marítimo, aeronáutico, espacial e do trabalho" (grifos nossos).

Inquestionável tratar-se de competência privativa constitucional ali estabelecida. Não restam dúvidas acerca dos limites impostos ao legislador, na regulamentação da matéria penal e processual penal.

Sobre a competência privativa, Araújo e Nunes Júnior (2018) pontuam:

Dessa maneira, cada uma das esferas federativas possui um rol próprio de competências, que, salvo hipótese de delegação, deve exercer com exclusão das demais. Assim, basicamente as competências privativas da União estão enumeradas nos arts. 21 e 22, as municipais encontram-se arroladas no art. 30 e as estaduais, no art. 25, todos da Constituição Federal. (p. 369)

Assim, induvidoso que só cabe à União — Poder Federal— editar leis processuais penais, sem delegação a qualquer outro ente. Tampouco, neste aspecto, cabe ao Conselho Superior do Ministério Público, cuja regulamentação constitucional nada traz em seu artigo 130-A (Andrade e Brandalise, 2017, p. 240), criar um instituto de negociação processual penal.

12 A Constituição Federal brasileira estabelece a reserva na competência para legislar em matéria penal ao Poder Federal, o que permitiu uma leitura sistêmica do que dispõem o princípio da legalidade e o princípio da reserva legal, previstos em seu artigo $5^{\circ}$, incisos II e XXXIX, respectivamente, ambos combinados com o artigo 22, inciso I: "Art. $5^{\circ}$ [... II - ninguém será obrigado a fazer ou a deixar de fazer alguma coisa senão em virtude de lei; [...] XXXIX - não há crime sem lei anterior que o defina, nem pena sem prévia cominação legal". "Art. 22. Compete privativamente à União legislar sobre: I - direito civil, comercial, penal, processual, eleitoral, agrário, marítimo, aeronáutico, espacial e do trabalho". 
Nesses termos, prevalece o posicionamento sobre a inconstitucionalidade formal do artigo 18, da Resolução 181, do Conselho Nacional do Ministério Público ${ }^{13}$, que apresenta frágeis argumentos contrários, conforme salienta Vasconcellos (2019):

Primeiramente, o fato de o STF reconhecer que resoluções do CNJ (e, por essa lógica, do CNMP) possuem caráter normativo primário para expedir atos regulamentares (ADC 12 MC e MS 27621) não autoriza que assim se introduzam mecanismos contrários ao ordenamento jurídico vigente e violadores dos direitos fundamentais. De modo semelhante, a regulamentação da audiência de custódia por resolução do CNJ é situação distinta, pois visa a consolidar um direito fundamental (convencionalmente previsto), de aplicação imediata, no ordenamento brasileiro. Ao contrário, o art. 18 da Resolução n. 181/2017 introduz espaço de redução e potencial violação a direitos fundamentais. Por fim, a autorização para a celebração do referido acordo é norma de matéria processual, pois aborda a realização ou não da persecução penal, além de acarretar uma renúncia da defesa ao contraditório e ao devido processo leal, permitindo a realização antecipada da jurisdição penal. (p. 141)

\section{DA OFENSA À "MÍNIMA JURISDICIONALIDADE POSSÍVEL" - NULLA POENA SINE JUDICIO}

Um dos pilares do sistema garantista desenvolvido por Luigi Ferrajoli, a jurisdicionalidade, afirma a necessidade de se transcorrer um processo para a aplicação de uma sanção penal. Desse modo, "a pena só pode ser legitimamente imposta após o devido processo legal, que funciona como filtro contra a opressão, o arbítrio e a violação aos direitos fundamentais" (Casara e Melchior, 2013, p. 135).

Nesse contexto, para harmonizar a justiça penal negociada — cuja principal lógica é a dispensa da instrução criminal — com o princípio da jurisdicionalidade, exigem-se cautela e racionalidade.

Na busca de um resultado equilibrado dessa equação, o caminho está em resguardar-se o momento adequado para a avaliação da proposta negociada e para a realização de eventual aceite. O "acordo" deve ficar processualmente localizado no momento imediatamente após o recebimento da denúncia, de forma a garantir um "mínimo de processo possível".

Exatamente nesse momento, ou seja, quando da análise jurisdicional sobre o recebimento (ou não) da denúncia é que o processo se inicia ${ }^{14}$. Não é constitucionalmente aceitável, diante da garantia do réu ao devido processo legal, qualquer imposição de sanções penais fora do contexto processual mínimo, entendido como garantia de

13 O Conselho Federal da Ordem dos Advogados do Brasil apresentou, perante o Supremo Tribunal Federal brasileiro, Ação Direta de Inconstitucionalidade (ADI n. 5793), na qual questiona os dispositivos da Resolução 181/2017, do Conselho Nacional do Ministério Público (CNMP).

14 Badaró (2014, p. 420), por sua vez, entende que o processo se inicia com o oferecimento da denúncia e se tornou completo com o seu recebimento. O que se pretende impedir é o acordo sem a denúncia ao menos formalizada, preferível que ocorra após pronunciamento judicial. 
que o Estado Juiz realizou a análise primária da existência de elementos necessários à propositura de uma persecução penal $1^{15}$.

Ao assegurar esse posicionamento, salienta-se que, sob a moldura de "acordo", as contrapartidas oferecidas ao acusado na Resolução 181 são similares às penas restritivas de direito previstas no artigo 44 do Código Penal brasileiro. Como exemplo, menciona-se a prestação de serviços à comunidade e a prestação pecuniária, previstas em ambos institutos, inclusive com o mesmo nomen juris, o que revela certo contrassenso da sua classificação como condição de um acordo negociado (pré-processual) se ambas são expressamente classificadas como pena, a ser cumprida após o transcorrer de inteiro devido processo legal.

Também pelo viés probatório a tese se sustenta. Sem novidade, é na formulação da hipótese acusatória que o Ministério Público publiciza o fato tido como criminoso e a respectiva qualificação jurídica, além dos elementos probatórios colhidos até então e as futuras provas que se pretende produzir, e ocorre uma verdadeira estabilização da demanda acusatória para o réu e sua defesa.

Aliás, evidenciado está que o fato definido na denúncia como crime não pode se modificar, em regra, durante todo o processo penal. É modificável apenas o seu grau de valoração. Nesse aspecto, vale lembrar Badaró (2014): "A imputação, em princípio, não se altera ao longo de todo o processo, mas os juízos que podem se formar a respeito de seu conteúdo podem variar, e certamente variam, em decorrência da progressão que ocorre na transformação da probabilidade em certeza" (p. 412).

Ou seja, a partir da formulação da denúncia, o acusado toma ciência exatamente de quais fatos é acusado e dos elementos de prova já relacionados a esse respeito, e pode então, a partir dessa garantia, também estar assegurada a oportunidade de refletir a respeito de eventual proposta de acordo.

Assim, à funcionalidade sistêmica esperada dos acordos e negociações penais, não basta o oferecimento de denúncia pelo Ministério Público, uma vez que a análise judicial acerca da imputação ministerial traz caráter de indispensabilidade. Isso evita que acordos sejam realizados sem o mínimo lastro probatório exigido para o início de uma ação penal — segurança jurídica esta que evita que a "crença" do ser humano (sujeito ao erro) investido de poder persecutório possa perpetuar-se-. desprovida dos requisitos probatórios legalmente e constitucionalmente exigidos no Estado Democrático de Direito, no qual a justa causa e seu controle se perpetuam como o instrumento de limitação do poder punitivo do Estado, diante da possibilidade de rejeição de uma acusação institucional.

15 Artigo 41 c.c. artigo 395, do Código de Processo Penal brasileiro. 
Neste momento, é importante observar que, ao buscar alinhar a Resolução 181 de 7 de agosto de 2017 com o previsto na legislação federal, em especial a Lei 9.099 de 26 de setembro de 1995 (Lei dos Juizados Especiais Cíveis e Criminais), o artigo 28 do Código de Processo Penal brasileiro, a Lei 12.850, de 2 de agosto de 2013 (no que se refere à homologação do acordo de colaboração premiada ${ }^{16}$ ), além de outros dispositivos legalmente vigentes, a alteração proposta pela Resolução 183, de 24 de janeiro de 2018, no intuito de importar uma "judicialidade" ao instituto proposto no artigo 18 da Resolução $181^{17}$, não apresenta qualquer capacidade legal de corrigir um vício de origem de toda a Resolução, qual seja, a referida norma não foi submetida ao devido processo legislativo, previsto para matéria penal e processual penal.

Assim, permanece a situação: não existe devido processo legal (penal) quando a norma que o impõe não é apta, seja por ilegalidade seja por inconstitucionalidade (Vasconcellos, 2019, p. 133).

Ainda no campo probatório, é digno de nota um retrocesso histórico acerca da confissão. Se, em superação a tempos inquisitoriais (Eymerich, 1993) nos quais, para a condenação, a confissão era a "rainha das provas", agora o Estado Democrático a reconhece como instrumento atenuante da pena ${ }^{18}$, e assim não poderá a confissão, instrumento propulsor da negociação penal, seguir um caminho de desconsideração do devido processo legal constitucional, de forma a assegurar que qualquer expectativa de persecução penal, ainda que não judicialmente avaliada, sirva de instrumento de coação à celebração de acordos de não persecução ${ }^{19}$.

16 "Art. $4^{\circ}[\ldots] \oint 7^{\circ}$ Realizado o acordo na forma do $\S 6^{\circ}$, o respectivo termo, acompanhado das declarações do colaborador e de cópia da investigação, será remetido ao juiz para homologação, o qual deverá verificar sua regularidade, legalidade e voluntariedade, podendo para este fim, sigilosamente, ouvir o colaborador, na presença de seu defensor. $\S 8^{\circ} \mathrm{O}$ juiz poderá recusar homologação à proposta que não atender aos requisitos legais, ou adequá-la ao caso concreto".

17 "Art. $18[\ldots]$ \& $4^{\circ}$ Realizado o acordo, a vítima será comunicada por qualquer meio idôneo, e os autos serão submetidos à apreciação judicial. (Redação dada pela Resolução 183, de 24 de janeiro de 2018) $\S 5^{\circ}$ Se o juiz considerar o acordo cabível e as condições adequadas e suficientes, devolverá os autos ao Ministério Público para sua implementação. (Redação dada pela Resolução 183, de 24 de janeiro de 2018) $\S 6^{\circ}$ Se o juiz considerar incabível o acordo, bem como inadequadas ou insuficientes as condições celebradas, fará remessa dos autos ao procurador-geral ou órgão superior interno responsável por sua apreciação, nos termos da legislação vigente, que poderá adotar as seguintes providências: (Redação dada pela Resolução 183, de 24 de janeiro de 2018) I - oferecer denúncia ou designar outro membro para oferecê-la; (Redação dada pela Resolução 183, de 24 de janeiro de 2018) II - complementar as investigações ou designar outro membro para complementá-la; (Redação dada pela Resolução 183, de 24 de janeiro de 2018) III - reformular a proposta de acordo de não persecução, para apreciação do investigado; (Redação dada pela Resolução 183, de 24 de janeiro de 2018) IV - manter o acordo de não persecução, que vinculará toda a Instituição. (Redação dada pela Resolução 183, de 24 de janeiro de 2018) § $7^{\circ} \mathrm{O}$ acordo de não persecução poderá ser celebrado na mesma oportunidade da audiência de custódia. (Redação dada pela Resolução 183, de 24 de janeiro de 2018)"

18 Artigo 65, inciso III, "d", do Código Penal brasileiro.

19 Sobre o tema merece consideração a questão dos acordos de transação penal, previstos na Lei 9.099, de 26 de setembro de 1995, na qual a ausência de justa causa, em interpretação adequada do que prevê a 
Reitera se que a relação de legalidade com o devido processo legal constitucional, não resta satisfeita com a simples formalização legal de instrumentos negociais no processo penal.

A instrumentalização da justiça penal negociada, em qualquer aspecto, passa obrigatoriamente pelo respeito aos princípios constitucionais orientadores do processo penal. Assim, qualquer violação ao princípio da reserva legal penal simplesmente fragiliza o sistema jurídico, em especial quando da propositura de acordos não submetidos à judicialidade estrita, ou seja, dispensados do controle correcional do Poder Judiciário, previsto de forma legal e nos estritos termos da previsão constitucional, portanto inadmissíveis no Estado Democrático de Direito ${ }^{20}$.

E mais, além do aspecto histórico, estudos empiricamente demonstram que a pessoa, frágil na posição de investigada, é capaz de confessar algo que não tenha realizado com intuito de se livrar de um processo penal que, indubitavelmente, deixa marcas (Ferreira da Silva, 2019).

Por fim, é interessante destacar que, entre as experiências que servem à discussão do tema ${ }^{21}$, a situação alemã foi promovida oficialmente pelo Conselho Nacional do Ministério Público como modelo a ser seguido, em consonância com o aqui proposto (Conselho Nacional do Ministério Público, 2017):

Poder-se-ia dizer que tal modelo se amolda a nossa realidade. Porém, há de se entender que um dos pontos que levaram à sua conformação — primeiro, pela jurisprudência; depois pela legislação — é a legitimidade: quem conduz os acordos

Súmula Vinculante 35, do Supremo Tribunal Federal, não deve permitir a homologação do acordo, já que em casos de acordo homologado não cumprido, expresso o entendimento da Corte constitucional de que ao Ministério Público se permite seguir com a propositura da ação penal, ou seja, para que ocorra o acordo devem estar presentes os pressupostos ensejadores da ação penal. Súmula Vinculante 35: "A homologação da transação penal prevista no artigo 76 da Lei 9.099/1995 não faz coisa julgada material e, descumpridas suas cláusulas, retoma-se a situação anterior, possibilitando-se ao Ministério Público a continuidade da persecução penal mediante oferecimento de denúncia ou requisição de inquérito policial".

20 Nesse sentido, oportuno ao tema, mas não à estreita discussão ora estabelecida neste artigo, o questionamento dos efeitos decorrentes do instituto administrativo do "acordo de leniência", inserido no sistema brasileiro pela Lei 12.846 , de $1^{\circ}$ de agosto de 2013, que em seu artigo 87: "Art. 87. Nos crimes contra a ordem econômica, tipificados na Lei n. 8.137, de 27 de dezembro de 1990, e nos demais crimes diretamente relacionados à prática de cartel, tais como os tipificados na Lei n. 8.666, de 21 de junho de 1993, e os tipificados no art. 288 do Decreto-Lei n. 2.848, de 7 de dezembro de 1940 - Código Penal, a celebração de acordo de leniência, nos termos desta Lei, determina a suspensão do curso do prazo prescricional e impede o oferecimento da denúncia com relação ao agente beneficiário da leniência" (grifo nosso).

21 Nos Estados Unidos da América, onde o sistema jurídico penal tem suas bases fundadas nos acordos e na negociação penal, a discussão sobre as consequências justas do instituto e das negociações promovidas pelos promotores "fora" do sistema judicial levaram à experiência como a do Estado do Alasca onde, em 1975, o então "Procurador-Geral" Avrum Gross suspendeu a prática de negociar apelos e sentenças em processos criminais de maneira experimental. 
é o juiz (=257c, n. 1 em 3, parte final, do StPO) [...] Nesse sentido, verifica-se que, no caso do acordo alemão; a-) seu resultado deveria acontecer durante audiência pública, devidamente registrada; b-) se não acontecido em audiência, seus fundamentos deveriam ser trazidos para registro na Corte; c-) ele deveria conduzir a um julgamento condizente com a culpa do acusado na prática do delito, pelo que incabível a negociação do conteúdo da acusação; d-) a confissão deveria ser apenas mais um elemento de prova [...] ao que se percebe, o paradigma trazido como justificador da informalidade não se aplica ao caso brasileiro, visto que, dentre outras diferenças, o acordo alemão, inicialmente criado sem previsão legal, previa sua realização em âmbito processual e presidido pelo juiz, algo que vai em sentido completamente oposto ao acordo de não persecução penal criado pelo Conselho Nacional do Ministério Público. (Andrade e Brandalise, 2017, p. 224, grifo nosso).

De todo o exposto, a Resolução do Conselho Superior do Ministério Público, especificamente quanto a determinar o acordo de não persecução penal antes do oferecimento da denúncia permite: a) sanções sem processo, b) insegurança probatória e c) acordos em processos sem justa causa.

Dessa forma, e também nesse aspecto, uma patente inconstitucionalidade por violação ao sistema acusatório se faz presente.

\section{A OBRIGATORIEDADE E AS MEDIDAS DE POLIITICA CRIMINAL DE MAIOR EFETIVIDADE}

De acordo com a Resolução 181, do Conselho Nacional do Ministério Público, o cumprimento de todas as obrigações impostas ao acusado acarretaria o arquivamento da investigação. Trata-se de evidente mitigação da obrigatoriedade do Ministério Público em dar início à ação penal, quando se deparar com fato tido por criminoso, presentes as condições da ação penal.

Sobre o princípio da obrigatoriedade, embora subsista alguma argumentação de que no Brasil não existe previsão constitucional de sua existência, como na Itália ${ }^{22}$, por exemplo, a verdade é que de uma inequívoca leitura sistêmica, a partir do disposto na Constituição Federal e no Código de Processo Penal, não existe em nosso sistema jurídico princípios de oportunidade e conveniência plenos, que permitam ao Ministério Público, nos termos do que pretende a Resolução 181 em questão, em seu artigo 18, ponderar e decidir a partir de critérios de política criminal com ampla discricionariedade.

A verdade é que, no Estado Democrático de Direito brasileiro, vige o princípio da obrigatoriedade, nos termos do artigo 129, I, da Constituição Federal23, que define a

22 O art. 112 da Constituição Italiana: "O Ministério Público tem a obrigação de exercer a ação penal".

23 Assim dispõe a Constituição Federal brasileira no "Capítulo IV - Das Funções Essenciais à Justiça", na "Seção I - Do Ministério Público", em seu artigo 129: "Art. 129. São funções institucionais do Ministério Público: I - promover, privativamente, a ação penal pública, na forma da lei". 
promoção da ação penal pública como uma das funções institucionais do Ministério Público, a ser realizada na forma disposta pela lei ${ }^{24}$.

Se é evidente que uma Resolução (norma jurídica de caráter administrativo, que tem por função disciplinar e regulamentar assuntos e formalidades de caráter interno das instituições) não tem o condão de superar disposições constitucionais e legais federais ${ }^{25}$, especialmente no caso em espécie, não é possível admitir a constitucionalidade e a legalidade de dispositivo dessa natureza, que se proponha a reduzir direitos e garantias do cidadão (que permita uma discricionariedade sobre a ação penal e a aplicação de uma sanção, sem o devido processo legal).

De outro lado, no Brasil, existe a aplicação de um "princípio da insignificância penal", pelo qual, com base na orientação jurídica da intervenção mínima do direito penal, é admitida uma exceção ao princípio da obrigatoriedade, por razões de política criminal, o que permite expressamente que o Ministério Público deixe de atuar - ou proponha acordos/negociação penal — ao menos em lesões inexpressivas ao bem jurídico tutelado. Nesses casos, a previsão dessa flexibilização segue nos termos da Constituição Federal ${ }^{26}$ e da Lei Federal regulamentadora da matéria constitucional ${ }^{27}$, sem outra hipótese em que isso possa ser admitido na preservação do Estado Democrático de Direito.

A experiência italiana, quanto à flexibilização do princípio da obrigatoriedade, permite ao Ministério Público deixar de atuar segundo o que preceitua a lei, discussão atualmente em voga, conforme delineiam Capparelli e Vasconcellos (2017):

A segunda solução - de maior interesse aos nossos fins - é representada pela possível ampliação normativa dos pressupostos de operabilidade do arquivamento, sobre o modelo de análogas reformas já experimentadas com sucesso em

24 E desta forma dispõe o Código de Processo Penal brasileiro quando, no Título III - "Da Ação Penal", prevê em seu artigo 24: "Art. 24. Nos crimes de ação pública, esta será promovida por denúncia do Ministério Público [...]" (grifo nosso).

25 A Constituição Federal brasileira bem estabelece a reserva na competência para legislar em matéria penal ao Poder Federal, o que permite uma leitura sistêmica do que dispõem o princípio da legalidade e o princípio da reserva legal, previstos em seu artigo 50, incisos II e XXXIX, respectivamente, ambos combinados com o artigo 22, inciso I: "Art. $5^{\circ}$ II - ninguém será obrigado a fazer ou a deixar de fazer alguma coisa senão em virtude de lei; [...] XXXIX - não há crime sem lei anterior que o defina, nem pena sem prévia cominação legal". "Art. 22. Compete privativamente à União legislar sobre: I - direito civil, comercial, penal, processual, eleitoral, agrário, marítimo, aeronáutico, espacial e do trabalho".

26 Assim dispõe a Constituição Federal brasileira: "Art. 98, A união, no Distrito Federal e nos Territórios, e os Estados criarão: I - juizados especiais, providos por juízes togados, ou togados e leigos, competentes para a conciliação, o julgamento e a execução de causas cíveis de menor complexidade e infrações penais de menor potencial ofensivo, mediante os procedimentos oral e sumaríssimo, permitidos, nas hipóteses previstas em lei, a transação e o julgamento de recursos por turmas de juízes de primeiro grau" (grifos nossos).

27 Lei Federal brasileira 9.099, de 26 de setembro de 1995, que dispõe sobre a Criação dos Juizados Especiais Cíveis e Criminais. 
outros ordenamentos estrangeiros ${ }^{89}$. Nesta direção, reentra a recente introdução do proscioglimento por particular pouca gravidade do fato. Dito proscioglimento per tenuidade - que pressupõe a existência de um fato típico de crime, de modesta expressividade lesiva mas não totalmente inofensivo ${ }^{91}$ — responde a duas fundamentais exigências constitucionais: 1) o princípio de proporcionalidade da intervenção repressiva penal, que proíbe, em conformidade com o cânone da ultima ratio sancionar penalmente condutas que parecem não merecedoras de pena no caso específico, e torna a declaração por tenuidade do fato uma verdadeira e própria "necessidade de justiça" em consideração da "adquirida consciência dogmática dos limites da tipicidade penal"; 2) a exigência de aliviar a sobrecarga do judiciário e de devolver efetividade ao princípio de obrigatoriedade da ação penal.

Em síntese, na linha do analisado, na Itália só seria tolerável a mitigação da obrigatoriedade em concreto benefício do réu, ou seja, quando em razões de política criminal o Ministério Público optar por não levar adiante o processo criminal, ser denunciar e nem propor qualquer acordo. Seria o arquivamento puro e simples, sem contrapartidas (p. 141).

A partir dessa experiência podemos considerar, em outro aspecto — para além da não atuação ministerial em determinados casos — não vinculado à discussão sobre obrigatoriedade da ação penal, que outras medidas devem ser avaliadas antes da incorporação legislativa dos acordos. Poderíamos conjecturar, como exemplo, a imposição legal da exigência de representação da vítima nos crimes contra o patrimônio, cometidos sem violência ou grave ameaça. Tal medida surgiria com grande efetividade como condição de procedibilidade, que poderia ser aferida alguns dias após os fatos, longe do calor do momento.

Outra medida de considerável impacto seria a alteração do artigo 89 da Lei 9.099/199528, que traz em seu bojo a suspensão condicional do processo. Ao modificar a exigência de pena mínima igual a 1 (um) ano pelo exato texto do artigo 18, da Resolução 181, ou seja, pena mínima inferior a 4 (quatro) anos ${ }^{29}$, o legislador certamente obteria êxito na sua empreitada "desprocessualizadora". Basta dizer que pes soas legalmente primárias, que cometerem furtos qualificados, estariam englobadas na suspensão, bem como um enorme contingente de jovens que acabam por praticar o tráfico privilegiado — não hediondo ${ }^{30}$.

28 "Art. 89. Nos crimes em que a pena mínima cominada for igual ou inferior a um ano, abrangidas ou não por esta Lei, o Ministério Público, ao oferecer a denúncia, poderá propor a suspensão do processo, por dois a quatro anos, desde que o acusado não esteja sendo processado ou não tenha sido condenado por outro crime, presentes os demais requisitos que autorizariam a suspensão condicional da pena" (art. 77 do Código Penal brasileiro).

29 "Art. 18. Não sendo o caso de arquivamento, o Ministério Público poderá propor ao investigado acordo de não persecução penal quando, cominada pena mínima inferior a 4 (quatro) anos e o crime não for cometido com violência ou grave ameaça a pessoa, o investigado tiver confessado formal e circunstanciadamente a sua prática, mediante as seguintes condições, ajustadas cumulativa ou alternativamente: [...]

30 Foi o decidido pelo Supremo Tribunal Federal no julgamento do HC 118.533. 
Seja como for, há alternativas diversas para o enfrentamento do cenário caótico da justiça criminal, que não se subsome apenas à justiça negocial que, ao apresentar tolerados prejuízos ao réu, deve ocupar o mais baixo degrau na escala das medidas implementadas ${ }^{31}$.

\section{CONCLUSÕES}

A justiça penal brasileira enfrenta um colapso. Números espantosos ${ }^{32}$ revelam a sobrecarga de trabalho ao qual juízes de todo país estão submetidos. Como consequência, observamos frequentemente garantias do acusado afastadas e decisões judiciais sem a profundidade desejada, justificadas por um princípio de celeridade e informalidade que, por vezes, superam a própria legalidade que lhes empresta validade.

Nesse cenário, pessoas são submetidas diariamente a condições desumanas de sobrevivência em presídios superlotados e sem as condições mínimas de saúde —algo similar à tortura — o que leva o Supremo Tribunal Federal brasileiro a declarar o estado de coisas inconstitucional ${ }^{33}$.

Tais situações exigem a reflexão por meio da sociologia e da criminologia crítica, e demandam tempo e assimilação social, o que hoje parece distante. Por outro lado, é através do processo penal que, desde já, medidas podem ser criadas para evitar, ou ao menos amenizar a situação.

No entanto, toda e qualquer modificação processual penal deve estar de acordo com o sistema acusatório vigente na Constituição Federal brasileira.

Assim, analisar questões inerentes às Políticas Públicas de Segurança, especificamente em relação às opções institucionais que possam fragilizar a segurança jurídica de um lado, com reflexos diretos a direitos e garantias fundamentais e, de outro lado, desrespeitar os próprios parâmetros de segurança institucional na constituição de instituições democráticas, é caminho obrigatório na defesa do modelo de Estado Democrático de Direito brasileiro.

Diante desses parâmetros, ao se acarear as garantias inerentes ao sistema acusatório com a Resolução 181 do Conselho Nacional do Ministério Público, o resultado obtido é a inconstitucionalidade formal e material de tal medida. Inicialmente, diante

31 A esse respeito, Pereira e Almeida (2019) esclarecem: "A segurança das instituições públicas é parâmetro contínuo na elaboração de diretrizes e políticas de segurança pública, por vezes ignorado, desconsiderado e negligenciado, enquanto que as 'forças de segurança pública', no exercício de poder repressor do Estado, continuam sendo empurradas para modelos de atuação repressiva desordenada e sem efeitos duradores" (p. 107).

32 O Relatório "Justiça em Números", produzido pelo Conselho Nacional de Justiça, menciona que em 2016 aproximadamente 2 milhões de novos processos penais de conhecimento abarcaram na justiça brasileira. http:// www.cnj.jus.br/noticias/cnj/85352-processos-criminais-representam-14-das-acoes-na-justica-estadual.

33 ADPF 347, julgada em 8/9/2015. 
da competência privativa da União em editar leis processuais penais; em seguida, pela ausência da mínima jurisdicionalidade possível, o que permite sanções penais sem ao menos o início do processo penal, em notória insegurança jurídica para o acusado.

As considerações da Resolução 181 sobre a "carga desumana de processos que se acumulam nas varas criminais do País", bem como sobre o "desperdício de recursos, prejuízo e atraso causados no oferecimento de justiça às pessoas", não são suficientes para justificar a suspensão de garantias legais e constitucionais dos cidadãos, daqueles que exercem, muito além da função de persecução penal, a de "fiscal da lei"34.

As medidas alternativas de conflitos penais que proporcionam celeridade nas soluções, já amplamente aplicadas aos casos de menor potencial ofensivo, somente teriam expectativa de aplicação em casos mais graves se assim o permitisse o Legislativo Federal (a referência se faz ao limite constitucional pétreo imposto a medidas dessa natureza), e jamais sob argumentos de que direitos e garantias individuais poderiam ceder espaço a melhores destinações de recursos financeiros do Ministério Público e do Poder Judiciário aplicados nos processos penais.

Não se pode pactuar com argumentos de que violação constitucional dessa natureza seria justificável, pois reduziria efeitos sociais prejudiciais da pena, e proporcionaria um "desafogamento" do sistema carcerário nacional às custas do Estado Democrático de Direito, do sistema acusatório e do devido processo legal. Concluise, assim, que medidas desprocessualizadoras são bem-vindas em dias atuais, todavia, apenas aquelas que trouxerem efetivo benefício ao cidadão sujeito à persecução penal e em conformidade com a Constituição Federal. Especificamente em relação à justiça negociada, suas hipóteses devem ser instituídas por lei. Consequentes acordos devem acontecer apenas após o recebimento da denúncia, ou seja, após verificada judicialmente a viabilidade de uma ação penal, em face dos elementos de fato e de direito submetidos à análise do juiz.

Como invocado nas próprias considerações justificadoras da Resolução 181, do Conselho Nacional do Ministério Público, se o Ministério Público dispõe de competência para promover investigações de natureza penal, desde que respeitados os direitos e as garantias ao cidadão, nos termos do acima discutido, não podem os dispositivos almejados no artigo 18 da respectiva Resolução permanecerem como legitimados pela própria Instituição. ${ }^{35}$

34 Artigo 127, caput e parágrafos, e artigos seguintes da Constituição Federal brasileira; artigo 178 do Código de Processo Civil brasileiro; artigo 610 do Código de Processo Penal brasileiro.

35 No curso da publicação deste artigo, foi promulgada a lei 13.964/2019 que regulamentou o acordo de não persecução penal no artigo 28- A do Código de Processo Penal. Todavia, permanecem íntegros os vícios constitucionais e democráticos arguidos, sendo certo que o trâmite legislativo escolhido fere o que prevê a própria Constituição Federal, quanto ao princípio da obrigatoriedade, a qual só tem ressalva quanto a crimes de menor potencial ofensivo, nos termos do artigo 98, I, da Magna Carta. 


\section{REFERÊNCIAS}

Andrade, M. F., E Brandalise, R. D. S. (2017). Observações preliminares sobre o acordo de não persecução penal: da inconstitucionalidade à inconsistência argumentativa. Revista da Faculdade de Direito da UFRGS, Porto Alegre, 37, p. 240 - 261..

Araújo, L. A. D., E Nunes Junior, V. S. (2018). Curso de direito constitucional (22 ed.). Editora Verbatim.

Badaró, G. H. R. I. (2014). Processo penal (2 ed.). Elsevier.

Camus, A. (2005). O homem revoltado (6 ed.). Record.

Canario, P. (2014, 27 de novembro). Em parecer, MPF defende prisões preventivas para forçar réus a confessar. https://www.conjur.com.br/2014-nov-27/parecer-mpf-defende-prisoes-preventivasforcar-confissoes.

Canotilho, J. J., E Brandão, N. (2016). Colaboração premiada e auxílio judiciário em matéria penal: a ordem pública como obstáculo à cooperação com à operação Lava Jato. Revista de Legislação e de Jurisprudência, 4000, p.17-38.

Caparelli, B., E Vasconcellos, V. G. (2017). Notas sobre a perene crise do princípio da obrigatoriedade da ação penal no ordenamento jurídico italiano. Revista Eletrônica de Direito Processual, 18, p. 118-149.

Casara, R. (2015). Mitologia processual penal. Saraiva.

Casara, R. e Melchior, A. P. (2013). Teoria do processo penal brasileiro: dogmática e crítica. Lumen Juris.

Conselho Nacional do Ministério Público (2017). Procedimento de Estudos e Pesquisas 01. Pronunciamento Final em Procedimento de Estudos. http://www.cnmp.mp.br/portal/images/Pronunciamento_final.pdf

Costa, J. D. F. (1997). Um olhar cruzado entre a Constituição e o processo penal. In: A justiça dos dois lados do Atlântico - teoria e prática do processo criminal em Portugal e nos Estados Unidos da América. Seminário realizado no auditório da Fundação Luso-Americana para o Desenvolvimento, em novembro. Versão portuguesa, Fundação Luso-Americana para o Desenvolvimento.

Coutinho, J. N. de M. (2015). Ignorando o passado, processo penal brasileiro revive Auflockerung nazista. http://www.conjur.com.br/2015-out-23/limite-penal-ignorando-passado-processo-penalbrasileiro-revive-auflockerung-nazista

Couture, E. (1987). Os mandamentos do advogado (3 ed.). Sergio Antonio Fabris Editor.

Departamento Penitenciário Nacional, Depen. (2017). Levantamento Nacional, de informações Penitenciárias. http://depen.gov.br/DEPEN/noticias-1/noticias/infopen-levantamento-nacional-de-informacoespenitenciarias-2016/relatorio_2016_22111.pdf

Eymerich, N. (1993). Manual dos inquisitores - Directorium Inquisitorum. Revisto e ampliado por Francisco de La Peña. (M. J. L. da Silva, trad.). Rosa dos Tempos.

Ferrajoli, L. (2002). Direito e razão: a teoria do garantismo penal. ( F. H. Choukr et al, trad.). RT.

Ferreira da Silva, J. (2019). O plea bargain e as falsas confissões: uma discussão necessária no sistema de justiça criminal. Boletim IBCCRIM, 318. IBCCRIM.

Figueiredo Dias, J. D. (1981). Direito processual penal. Coimbra Editora.

Granduque J., \& Caio Jesus (2017). Albert Camus: a justiça entre o avesso e o direito. LiberArs. 
Lopes Junior, A. (2014). Direito processual penal (11 ed.). São Paulo: Saraiva.

Maldonado, A. M., E Chorres, H. B. (1). El Estado en la gestión del conflicto: la reforma del proceso penal en Latinoamérica. Opinión Jurídica, 9(17), 57-70. https://revistas.udem.edu.co/index.php/ opinion/article/view/758.

Morais da Rosa, A., E Lopes Jr., A. (2017). Saldão penal e a popularização da lógica da colaboração pelo CNMP. https://www.conjur.com.br/2017-set-22/limite-penal-saldao-penal-popularizacao-logicacolaboracao-premiada-cnmpneg

O Globo. (2019, 16 de setembro). Preso em São Paulo, Tommaso Buscetta delatou mais de 300 mafiosos italianos. https://acervo.oglobo.globo.com/em-destaque/preso-em-sao-paulo-tommasobuscetta-delatou-mais-de-300-mafiosos-italianos-10493312

Pereira, C. J. L. (2002). Princípio da oportunidade de justiça penal negociada. Juarez de Oliveira.

Pereira, C. J. L. (Org.), E Almeida, D. (2019). Segurança e risco em instituições democráticas, segurança pública, instituições democráticas e seus elementos históricos, políticos e econômicos. Quartier Latin.

Prado, G. (2005). Sistema acusatório. A conformidade constitucional das leis processuais penais (3 ed.). Editora Lumen Juris.

Roxin, C. (2003). Derecho procesal penal. Editores Del Puerto.

Sanguiné, O. (2001). Clamor público como fundamento da prisão preventiva. Em S. Shecaira (Org.). Estudos criminais em homenagem a Evandro Lins e Silva (criminalista do século), pp. 257-296. Editora Método.

Sen, A. (2011). A idéia de justiça. Companhia das Letras.

Schunemann, B. (2013). Estudos de direito penal, direito processual penal e filosofia do direito. Marcial Pons.

The New York Times. (1975, 12 de julho). Alaska ending plea bargaing to raise confidence in justice. https:// www.nytimes.com/1975/07/12/archives/alaska-ending-plea-bargaining-to-raise-confidence-injustice.html

Vasconcellos, V. G. (2019). Barganha e justiça criminal negocial: análise das tendências de expansão dos espaços de consenso no processo penal brasileiro (2 ed.). Editora D’Placido. 